TRANS $\cdot$ núm. I3 $\cdot 2009$

DOSSIER $\cdot 107-118$
Nuestro lenguaje común es polifonía -afirma Martha Lavey (2004: xi)- aunque constantemente estamos buscando ese lenguaje común que perdimos cuando se derrumbó la Torre de Babel. El objeto de este estudio, la obra de teatro contemponáneo sueca Utvandrarna, confirma la cita anterior. En Utvandrarna la heteroglosia juega un papel muy importante en relación con una serie de narraciones que el público está invitado a construir en la representación. Cuando la obra se representaba en diferentes lugares de Finlandia, el sobretitulado se hizo necesario con mayor frecuencia que en las representaciones suecas (dirigidas a un público que hablaba sueco) para facilitar la comprensión del discurso y, por tanto, la construcción de las narraciones. El propósito del presente trabajo es estudiar el uso e importancia de la heteroglosia y de la alternancia de códigos, tanto en la caracterización (auditiva) como en la escenografía (visual) que conforman la experiencia teatral completa.

PALABRAS CLAVE: Traducción teatral, sobretitulado, construcción de narraciones, heteroglosia y alternancia de códigos, polifonía en la representación escénica.

\title{
Noni sosökokeror alolotoså asyl? Constructing Narratives of Heteroglossia in the Swedish Performances of Utvandrarna on the Finnish Stage
}

SiRKKu Aaltonen

University of Vaasa, Finlandia
Our common language is polyphony, claims Martha Lavey (2004: xi), although we are constantly looking for the common language we lost when the tower of Babel came down. The Utvandrarna, a contemporary Swedish play at the centre of this study, supports this reading. In Utvandrarna, heteroglossia plays a prominent role in a number of narratives that the performance invites the audience to construct. When the play toured Finland, surtitling was needed even more extensively than in the original Swedish performances (to Swedish-speaking audiences) to aid discursive comprehension and through that the construction of narratives. The aim of the present study is to study the use and significance of heteroglossia and codealternation both in the characterization (auditive) and in scenography (visual) in the total experience of theatre.

KEYWORDS: theatre translation, surtitling, constructing narratives, heteroglossia and code-alternation, polyphony on stage 
11. The main title of my article derives from the lines of a Swedish immigration officer who is interviewing foreign asylum seekers on their landing in a container in Sweden. His lines are not Swedish but pig Latin', incomprehensible language to the outsiders. And that is what the immigrants are, outsiders. At the same time the audience, although they also hear the officer's pig Latin, learns what his question is as they can read the translation in the surtitle on the backdrop: Ni söker altså asyl? (Act 2, Part 3, Scene r) «so you are applying for asylum?». This is only one of the many instances of heteroglossia ${ }^{2}$ in the Swedish play Utvandrarna (emigrants) which toured Finland in the spring of 2007 , performing to both Finnish-Swedish and all Finnish audiences. Apart from pig Latin, the audiences heard Swedish, Bosnian, Persian, Russian, and English on stage. The scenography supported the wealth of languages and voices, or the play's heteroglossia, which marked the actors in relation to their origin and background. Surtitles and projections of other texts on either the backdrop or different screens were an integral part of the performance for all audiences irrespective of what their native language might have been. Depending on whether the audiences in Finland were Finnish- or Swedish- speakers, the amount of speech needing surtitling varied.

The average mainstream theatre-goer seldom encounters surtitles as part of the scenog-

I In Swedish, they are described as rövarspråk, language of thieves, in which additional letters and syllables disguise what is being said or asked. The principle is similar to that of the English pig Latin.

2 I use the term heteroglossia in the Bakhtinian sense of the multiplicity of social voices linked and interrelated dialogically in a novel. As I see it, I could have used polyglossia as well. (see e.g. Hawthorn, 2004). They would, however, focus the attention somewhat differently though, and heteroglossia is a more accurate word for the study of narrative construction

raphy. This is because surtitling is commonly seen in opera-productions and in international theatre festivals where foreign language theatre productions are shown to audiences of different languages (see, e.g. Griesel, 2005; 20073) and which do not, as a rule, attract mainstream theatre-enthusiasts. Also Utvandrarna, although it was touring another Nordic country, probably had somewhat different audiences than those usually visiting Finnish theatres. The play is exceptional in that heteroglossia is such an integral part of its narrative that it always needs surtitles wherever it is performed: even in its home country, Sweden, or before the Swedishspeaking audiences in Finland. In this, it has great similarities with some other contemporary plays which use heteroglossia as one of the elements of their narratives, such as Tony Kushner's Homebody/Kabul, which the Artistic Director Martha Lavey described as a record of a world in which the mother tongue [...] has been lost (quoted in Kushner, 2004: xi). In Homebody/ Kabul, the audiences could hear (depending, of course, on how the production was constructed) Esperanto, various tribal languages of Afghanistan, English, French, the Dewey Decimal system and Milton's computer language.

Surtitling as an aid for the audience to follow the plot is not the only option in foreign language theatre. Also summarizing or simultaneous interpreting can be used, in particular if the play is not heavily text-based (see Griesel, 2005: 3). With plays like Utvandrarna, these would have been out of the question.

In what follows, I propose to explore the play from two different angles with the question that I have set for the study: how does heteroglossia (in characterization) and surtitling

3 Griesel (2007: 2) sees similarities between these but also with film-subtitling, but emphasizes that there are substantial differences among them too. 
(in scenography) (re)frame the narratives for the two audiences with two different mother tongues, Finnish and Swedish? In exploring the characterization, I will focus primarily on how heteroglossia is inserted in the dialogue and how it relates to the staged authenticity of the play. In scenography, I will investigate the way surtitles have been used to support discursive comprehension of the narratives which can be derived from the production and to reduce the burden on the reception process.

My material consists of the play Utvandrarna, which, in itself, is already an intralingual translation (an adaptation, some scholars might want to call it) of a four part epic by one of the canonical Swedish writers Vilhelm Moberg (1898-1973). His epic consists of the novels (Utvandrarna 1949, translated into English as Emigrants in 1951), Invandrarna I952, translated as Unto a Good Land 1954), Nybyggarna 1956, translated as The Settlers 1956), and Det Sista Brevet till Sverige 1959 (translated as The Last Letter to Sweden 196I). The epic was translated (dramatized is another term that could be used here) into a play by an Iranian-born (she moved to Sweden at the age of two) Farnaz Arbabi. When Moberg wrote his epic on the the experiences of the Swedes who emigrated to North America in the $19^{\text {th }}$ century, Arbabi reversed the narrative and made contemporary immigrants, refugees and asylum seekers, the protagonists of her play. The land of hope for Moberg's characters was North America, whereas Arbabi's characters are looking for a chance to survive in Sweden. The production of the play was the result of cooperation between Regionteatern (the regional theatre) Blekinge Kronoberg and Riksteatern (the national theatre).

For the study I have used a written Swedish script, the blueprint for the first production of the play in Sweden, which I received from the producers at Riksteater. In the script, the heteroglossia, concretely the non-Swedish lines, is indicated by italics. The italicized lines (in the performance, the surtitle texts) were written in Swedish in the script, but spoken by the characters in Bosnian, Persian, Russian, Ukrainian, pig Latin or gibberish, and they were projected behind the characters in Swedish or Finnish in the performance. I also had a DVD of the production, which was also the one that the Finnish surtitler-translator had at her disposal when writing the surtitles in Finnish. My analysis of the production is, undoubtedly, also influenced by the performance in Swedish that I saw in the Swedish theatre in my bilingual hometown Vaasa in Finland. In that particular performance, the texts projected on the wall as well as the surtitles were in Swedish.

When the production toured the Finnishspeaking towns in Finland, all written texts in the scenography were in Finnish. A written script of the Finnish surtitles was given to me by the Finnish translator Maria Kynsijärvi, who I also consulted about the construction and use of the surtitles in this production and in general. For her translation process, she had seen the production a few times in Sweden and then worked on the basis of the Swedish manuscript and the DVD.

My analysis is based on a desire to understand what narratives the production offers to two different audiences and the theatrical signs it uses for doing this. In my aim to understand, I have undergone, what Jaqueline Martin (quoted in Martin and Sauter, 1995: 124) describes as a hermeneutical process, that is, I have started from my own prior knowledge and expectations and arrived at a possible interpretation which is basically subjective but which has taken into account the relationship between the different elements of the performance (sce-
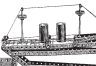

109 


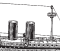

nography, characterization) and their effects on the whole.

In my analysis, I am using the term nar110 rative as defined by Mona Baker to describe a way of organizing the chaos around us into meaningful wholes. It is the principal and unavoidable mode by which we experience the world. Narratives are the stories we tell ourselves and other people about the world(s) in which we live. The stories are constructed, not discovered, as we are making sense of reality (Baker, 2006: I69). When we see a theatre performance we will automatically try to construct a narrative of what we see. The same process has happened when the practitioners, the playwright, producer, director, actors, light and sound technicians, costume- and make-up-artists and set designers have started their work on Utvandrarna. Also the translator is engaged in this process. The narratives ${ }^{4}$ are not necessarily the same for all participants, and, as Carlson (2006: 3) has suggested, although theatre is the most local of arts and commonly the dramatist and audiences share a highly specialized language which is unique to theatrical communication and the languages of the stage (e.g. particular theatrical conventions, acting styles, and the potential meaning of each aspect of the production ranging from the theatre building to the smallest particular gesture), productions are still open texts. The audiences or different members of the audiences may, for example, focus more on certain narratives than others or ignore some narratives entirely. The narratives that they construct are also likely to be framed by extra-theatrical material such as posters and theatre programs, previews, reviews and

4 Baker (2006: 169) uses narrative interchangeably with story. advertisements on the Internet and the other media (see Carlson, I990).

As Baker (2006: 28) sees it, narratives we derive from what we experience or that we construct the others may be of different types. Ontological narratives are the personal stories of the self that we tell ourselves about our place in the world and our personal history.

Both the artistic director and members of the audiences inescapably construct personal narratives of the dramatic figures they see in the production. Some interpretations may be foregrounded by a number of theatrical signs (acting style, speech, costume, non-verbal communication etc), others by what they say or what others say about them ${ }^{5}$. Collective narratives, then, are shared narratives that are told and retold by members of a society over a long period of time (in the media, literature, education), and they provide the blueprints for ontological narratives. Collective narratives are made up of many personal stories (ib.: 29-30.). The audiences of Utvandrarna are likely to share many collective narratives of their culture, country, emigration in the $19^{\text {th }}$ century as well as immigration in their contemporary world(s). An important collective narrative may also be the recognition of the reversal of Moberg's admiration of the Swedish emigrants. In Arbabi's play they have become the despised immigrants. There may also be clashes between ontological narratives and collective narratives, which may be the case in Utvandrarna when the police behave brutally towards some characters on religious or moral grounds, and someone's personal narrative may not agree with this view of the police. Public narratives are more official versions of collective narratives and circulated among social and

5 A good overview of textual means in characterization in Pfister (I988: I83ff.). 
institutional formations, such as the family, religions and educational institutions, the media and the nation. They are the official «truths» of societies (ib.: 33). In the analysis of Utvandrarna, also the most extensive of the narratives, the master narrative (ib.: 44-45) may become activated. This is the large narrative of our time and age and consists of concepts such as Globalization, Conflict Zones, Progress, Efficiency and the Future of Our Planet.

For my study of the heteroglossia in Utvandrarna, the most important narratives are the ontological narratives of the characters, the collective narratives they are retelling, the public narrative which is the «baggage» the audiences carry with them to the performance and also the master narrative they share. The latter two they may compare with the narratives they can derive from the production.

\section{HETEROGLOSSIA AND CODE- ALTERNATION}

In Utvandrarna, heteroglossia involves a number of languages ${ }^{6}$. Six of these function as icons of natural languages. Some asylum seekers (the actors) speak Bosnian, some Persian, and others Russian. Some try to communicate with each other or the local people at their destination, Sweden, in English. There are also the two artificial languages, a kind of pig Latin and gibberish, spoken by the Swedish Immigration Board and a Swedish shop assistant respectively.

According to Marvin Carlson (2006: 3), theatre is the most iconic of arts which uses raw materials of life - objects, human bodies etc. - as means of imitation. The imitation may be based on some perceived resemblance (in Utvan-

\footnotetext{
6 In this respect, polyphony would be a more appropriate term.
}

drarna, the unbearable conditions in the container carrying the asylum seekers were achieved mainly with lights, sounds and a projection of a thermometer showing the rise of the temperature) or rely entirely on theatrical conventions (although people speak different languages, they all still understand each other). The signs may also be identical to what they represent, such as the foreign languages in Utvandrarna.

A great deal of the heteroglossia in Utvandrarna takes the form of code-alternation, that is, the characters are switching between two or more languages. In this study, I use code-alternation as a convenient label for the use of more than one language in the play by the same character either turn-internally or turn-externally. It is a cover term for both language transfer, language alternation for a structurally bound unit (word, phrase, sentence), followed by return to the original language, and code-switching, language alternation without a predictable point of return to the first language. Code-switching invites other parties to switch languages «until further notice», while transfer has no such consequences7. In the analysis of Utvandrarna, it would be futile to try to identify the two types. The characters on stage do not imitate codealternation, nor are we supposed to perceive the switch between languages as code-alternation.

\section{HETEROGLOSSIA AND CODE- ALTERNATION IN CHARACTERISATION}

Some of the heteroglossia in Utvandrarna is placed in the narrative of the Bosnian couple Karl Oskar and Kristina in Part I, where seven scenes out of the total of Ir include code-alternation between Swedish and Bosnian. Part 2 is

\footnotetext{
7 This definition is used, for example by Auer as quoted in Saari (2006: I43).
} 
14. the narrative of the journey to Sweden, first in a truck and then in a container onboard a ship. This narrative is spread over I3 scenes, of which

1127 have alternation between Swedish, English, Bosnian, Persian and Russian. Two scenes are entirely in Russian and two in Persian. Two scenes are in Swedish. Finally, there is far less code-alternation in the narrative in Act II, part 3, set in Sweden. While the prominent languages in Act I were Bosnian, Persian and Russian, in Act II the alternation is mostly between Swedish and English. The second act has also two scenes which involve alternation between Swedish and the artificial pig Latin and gibberish.

What we hear or read is thus not an iconic artistic representation of code-alternation. The languages themselves are icons of natural (or artificial) languages, whereas the code-alternation in the play is not iconic. In individual scenes, codealternation is usually turn-external, and there is no obvious explanation as to why the characters all of a sudden switch to another language. This is a significant deviation from authentic codeswitching which usually functions in reported speech, marking a change of participant constellation, a topic shift, a group identity marker etc. The following exchange is from the beginning of the play and takes place between Berta, a village woman, and one of the future immigrants, Kristina. The italicized lines are spoken in Bosnian (although written here in Swedish for the surtitles), non-italicized lines are spoken in Swedish and there is no apparent reason why the speakers change languages. The change here is also an example of turn-external alternation:

BERTA Sitt still nu. (Sit still now)

KRISTINA Men jag vill inte ha bandage. (But I don't want a bandage)

BERTA En skada är en skada och måste tas hand om. (A wound is a wound and must be taken care of)
KRISTINA Det gör inte ont. (It's not hurting)

BERTA Nu får du göra slut med dina barnsligheter.

(Now you must stop being so childish)

KRISTINA Hur länge måste jag gå med den här.

(How long do I have to wear this)

(Act I, Part I. p. 2)

Code alternation can also be turn-internal without any obvious reason for the switch either, as in the following lines by Kristina, who is terrified at her husband's blasphemous accusations towards God of their poverty:

KRISTINA Karl Oscar! Du smädade Gud! (Karl Oscar, you were slandering God)

Paus (pause)

Gud tröste dig för det du gjorde! (May God forgive you for what you did)

(Act I, Part I, Scene 5, p. I6)

The code can be alternated several times during one scene even when the characters on stage do not change, as shown by the following sequence from Act I, Scene I (pp. 2-5): Bosnian (4 lines) - Swedish (3) - Bosnian (3) Swedish (I with an alternation) -Bosnian (3) - Swedish (9) - Bosnian (2).

In the external world of the play, the hermeneutical «baggage» or prior knowledge of theatrical conventions concerning illusion and mimesis help to explain to the audiences obvious inconsistencies of the alternation (that it is not iconic), that

- the little daughter of the Bosnian couple has no lines in Bosnian

- the elderly father of the Bosnian protagonist has only two lines, one of which is in Bosnian and the other in Swedish

-although the characters have communication problems during the journey and when they finally come to Sweden, they are, in fact, 
able to communicate most of the time with each other (in Swedish). This is illustrated by the following example from the journey. I have indicated in bold the languages the characters are assumed to speak, although on stage the audience hears them speak Swedish:

DANJeL (Persian) Karl Oskar. Jag har ett bud till dig. (KO, I have a message for you)

KARL OSKAR (Bosnian) Från vem? (From whom)

DANJel (Persian) Från Gud. (From God)

kARL oskar (Bosnian) Från Gud...? (From God)

Danjel (Persian) Gud sa till mig att vi skulle ses här. Han sade att du ska visa mig vägen. Jag lever i förföljelsens tid i mitt hemland. Jag är hindrad att bekänna min tro. (...) (God told me that we would meet here. He said that you will show me the way. I am persecuted in my own homeland. I am prevented from professing my religion)

KRISTINA $(\ldots)$

DANJEL (...)

ROBERT (Russian) Ett svin I Europa mår bättre än vad en greve gör hemma. (A pig in Europe lives better than a count is at home)

$$
\text { (Act I, Del 2, Scene 15, p.46) }
$$

\section{HETEROGLOSSIA, CODE-ALTERNATION AND THE (RE)FRAMING OF THE NARRATIVES}

Most of the code-alternation has significance only in the external world of the play, that is, the narratives the audiences can construct from what they hear and/or see. Only some of the alternation also has dramatic significance within the fictional world of the characters. Heteroglossia in Utvandrarna has been used to frame the narratives of emigration and immigration spatially, temporally and morally. In ontological narratives, the asylum seekers come from very different backgrounds and leave their home countries for very different reasons. They then arrive in a new country where communication problems are very serious (one dies as a result of them) and most of the time goes in uncertainty as to whether they will be allowed to stay or not. They do not understand what is going on. The heteroglossia, extending to the voices of Moberg's emigrants, also constructs the moral frame, or perspective, in communal narratives which the audiences can compare with public and master narratives. The only foreign language the audiences are expected to understand without surtitles is English, and in some contexts, the effort to use English symbolises the search for a common language in order to be able to share their pain and worries. As Martha Lavey (quoted in Kushner, 2004: xi) has expressed it, Humankind is burdened by the need to express a common condition but without a common language to do so. Whether English is the common language is left open. English lines are not surtitled and thus not immediately accessible to all.

In what follows, I will take a closer look at how some of the possible narratives are framed ${ }^{8}$ by heteroglossia in the dialogue in Utvandrarna. Three narratives in particular are of interest:

\section{I. The ontological narratives constructed by the play the audiences witness on stage}

The audiences make sense of what they see on stage by trying to organise it into a meaningful whole by constructing a narrative of the signs that are on offer. Although audiences come to

8 Framing, according to Mona Baker (2006: I06) is an active process of signification. Frames are structures of anticipation or strategic moves which are consciously initiated in order to present a movement or a particular position within a certain perspective.

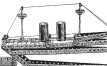

113 
14. the play with different prior knowledge and expectations, the programme and posters, previews and advertising have already foregrounded certain narratives. In Utvandrarna, the ontological (personal) narratives derive from the characterization and acts of the asylum seekers who migrate to Sweden from different parts of the world. The emigrants leave Iran, the Balkan States, and the former East European countries either in the hope of a better future or to escape starvation, hostility, prejudice, or unbearable living conditions. None of them has a work or residence permit, and they are therefore forced to wait in uncertainty while their applications are being processed. In the play, the majority (in fact, all but one) have their applications rejected.

The ontological narratives are framed (temporally) by two Acts (before Sweden and in Sweden) or by three Parts (at home and the journey and in Sweden), and they are spread over some 50 scenes. It is suggested to the audiences that the emigrants all speak their own language, which, is occasionally also heard on stage and, on such occasions, interpreted in surtitles into Swedish/Finnish. Already the arrival in the new country could be taken as a bad omen. Communication problems are practically unsurmountable. The language they hear is incomprehensible, which is indicated by the pig Latin (rövarspråk, 'the language of thieves') or the shop assistant's gibberish (marked in the text as obegripligt, 'incomprehensible' Act II, Part 3, Scene I2, p. I05). This is how the questions of the immigration officers sound to the asylum-seekers:

MICKE I Noni sosökokeror alololtotsoså asyl? MICKE 3 Vapar kopom-meper nipip ipifråpån? MICKE 2 urhal ängelal arhal inal aritval ial Sverige

$$
\text { (Act II, Part 3, Scene I, pp.77-78) }
$$

Not only the language but also the officers themselves are like from another world. They are not identifiable nor is there any effort on their part to help the newcomers. Even the Swedishspeaking audiences are seen to need the help of the surtitles to understand the questions.

The personal narratives thus use heteroglossia (on stage materialized as polyphony) in acting to construct the narratives which derive also from problems in communication. Languages, both natural and artificial, make communication difficult both within the world of the emigrants but also between them and the outsiders in the new land.

\subsection{The communal narrative underlying the play}

The first identifiable communal narrative derives from the suggested parallelism with Vilhelm Moberg's well-known epic. Moberg's description of the journey of Swedish emigrants to America is suggested by a number of framing devices, some extra-theatrical paratexts and other theatrical signs in the play. The setting of the play is all Swedish and recognizably the same that Moberg used in his epic. The parallel is suggested by retaining the Swedish personal and place names and only using English names of the people at the destination (priest Jackson Act II, part 3, Scene I7, p. II8). When they first arrived in America, their experience of the language of people who were meeting them must have been very similar to the pig Latin of the Immigration Officers in Utvandrarna. Codealternation in Utvandrarna then also symbolises the experience of the Swedish emigrants to North America over a hundred years ago when in the $19^{\text {th }}$ and early $2 \mathrm{O}^{\text {th }}$ centuries about I. 3 million Swedes left Sweden for North America. They were at the centre of Moberg's epic. The 
Swedes leaving their country met with immigrants from other countries, and must have had similar communication problems as the characters audiences see on stage.

Although not all audiences may be familiar with Moberg's epic, many are likely to be familiar with other communal narratives of emigration. Both Finland and Sweden lost many of their citizens and there are many stories about and by them. Many audience members may have family and relatives in both North America and Canada, and many have old letters and diaries that describe this history. There maybe surprise visits from family members they did not even know existed. Most of the stories are success stories, while failures seldom got reported back to the old homeland. A great number of literary works also retell the stories of the big emigration of the $19^{\text {th }}$ century.

\subsection{Public and Master Narratives}

Utvandrarna starts with a projection of a text from the beginning of Moberg's novel of the same name (i.e. Utvandrarna) and finishes with a reframed (updated) version of it, (re)framing narrative we derive from Arbabi's play with a contemporary master narrative and the intolerable and inhuman conditions of asylum seekers. The linking of the situation in 2006 with that some 150 years ago suggests the master narrative of large population movements. Throughout history there have been vast population movements of which the contemporary cultural movements and diasporas are associated with many large-scale changes (in themselves master narratives), such as globalization, wars and economic hardships. The migration to Sweden is one of the elements in this master narrative. The public narrative, which the audiences may be familiar with, is an official construction mostly of immigration and far less of emigration (the so-called brain-drain could be one of emigration). Until 1967, entry to Sweden was free - Sweden needed a labour force but that year new immigration controls were introduced, according to which non-Nordic immigrants needed a residence and work permit. Entry became much more difficult, but this did not decrease the number of those seeking a better and safer future for themselves and their children. Many have been disappointed, as the official statistics show: in 2007, there were 36.207 asylum applications, half of which were refused.

The audiences who come to see Utvandrarna are thus offered a number of narratives, each foregrounded in several ways. Parts of the ontological narratives of the characters are constructed when the actors alternate between Swedish and other languages. The actors use foreign languages indexically ${ }^{9}$ to suggest their foreign origin, while the languages themselves function iconically ${ }^{\mathrm{ro}}$. A collective narrative rises from the heteroglossia. The audiences are offered firstly a strong parallelism between what they see and Vilhelm Moberg's four-part epic. This already starts at the beginning of the play when the actors gather on a dark stage, and an extract from Moberg's Utvandrarna is projected on the backdrop. These projections continue throughout the play. The names of people and places are Swedish and those that Moberg used. Heteroglossia also foregrounds the collective narrative of immigrants in contemporary Sweden. While they are usually seen

9 An index functions by virtue of an existential connection or spatiotemporal (physical) contiguity between sign and object (Snell-Hornby, 1997: 189).

ro Icons function by virtue of an inherent similarity (likeness) between the sign and object (Snell-Hornby, I997: I89).

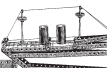

115 
11. as a challenge to the Nordic welfare system, the narrative here foregrounds the perspective of the immigrants themselves. They are leaving the devil they know for the devil they do not know. The combination of the two collective narratives prepares the ground for yet another narrative, that of a common experience some I50 years apart.

The audiences come to the productions with prior knowledge of their own country's public narrative of Immigration (welcomed workforce, burdens to the social welfare system, refugees who need protection, asylum seekers who need to become assimilated to the receiving culture but who refuse to do so, people who are entitled to retain their own language and culture etc). The master narrative then links the play with events where we all are actors ${ }^{\mathrm{II}}$ : vast population movements, unemployment, inequality, poverty, wars etc. are all possible master narratives for the play.

\section{CONSTRUCTING THE NARRATIVES IN THE SURTITLES}

According to Griesel (2005: 2), surtitling is distinguished by a number of features from more canonical theatre translation.

- Surtitles are used with foreign language theatrical productions.

-The source text is the performance as a whole which needs to be taken into account when translating (here it has much in common with interpreting processes).

- It is an additive form of translation in that it extends the source text by the dimension of translation (ib.: 5).

Surtitling has similarities with interpreting in that it depends on the situation and relies on

II See Baker (2006: 44).

previously prepared elements. It also has similarities with subtitling in that the minimum and maximum projection times must be followed ${ }^{\text {I2 }}$. Usually the speech has to be condensed, which can be done using a number of techniques. This has, however, been beyond this study.

The present study includes two productions in Finland whose language profiles are different. For the Swedish-speaking audiences, the set of texts that they could use for the construction of the narratives were:

I. The reference text: canonical, original prose text (in Swedish by Moberg)

2. The non-canonical original drama text (on stage in Swedish and foreign languages by Arbabi)

3. The non-canonical translation of drama text (Swedish surtitles)

For the Finnish-speaking audiences more texts may have been involved:

I. The reference text: canonical original prose text (the Swedish epic by Moberg)

2. The non-canonical original drama text (on stage: Swedish and other languages)

3. The canonical translation of original prose text (Moberg in Finnish)

4. The non-canonical translation of drama text (surtitles of Swedish and other languages in Finnish)

As becomes clear from the above lists of texts, the prior knowledge of the audiences may have varied considerably. Both productions may also have had bilingual viewers whose hermeneutical baggage ${ }^{\mathrm{r} 3}$ would have been some other type of mixture of the two. The Finnish

\footnotetext{
I2 For opera surtitling, see, for example, Virkkunen (2004: $247 \mathrm{ff}$.)

r3 Martin (I997: 125) uses this as a synonym for prior knowledge.
} 
surtitler used mainly text 2 in the form of a DVD recording.

In scenography, the extracts from Moberg's original prose text were projected as continuous texts on the backdrop in the Swedish production, whereas the surtitles were not adapted from the Finnish translation of Moberg's work. Also, they were, at most, two to three lines long. In the production for the Swedish audience, the location of the surtitles changed in that they sometimes appeared above the speaker in a dialogue and at other times as lines between them which changed according to who was speaking. There was no risk of confusion of whose lines were interpreted for the audiences. Some of the surtitles were projected on the backdrop, others appeared on the screen, which was used to identify different locations and also used for shadow play. In Finland surtitle lists were not part of the spectacle, and they always appeared in the same plays. This depended largely on the technical equipment that was available for the performances.

My general finding was that surtitles helped to integrate code-alternation into the narratives for the Finnish theatre audiences mainly in the way they were related to the visual signs of characterization on stage. Most importantly, surtitling emphasized the perspective of the emigrants, people leaving their country rather than the perspective of Sweden as their destination. Ontological narratives thus supported communal narratives of the reasons for emigration and undermined those of fair and human treatment of people in need. Surtitling supported the reception of the audiences in a number of ways:

I. English was not surtitled in either of the two productions (Finnish or Swedish) which emphasised its foreignness to the characters in the play. Also the audiences experienced it as a foreign language.

2. In the Swedish production, the pig Latin of the Immigration Board was projected in translation on the wall, while the gibberish of the Swedish shop assistant was not. In the Finnish production, both surtitles appeared as pig Latin. The gibberish was turned into pig Latin to avoid the sound of Swedishness which was audible in the shop assistant's speech. For the emigrants, the languages were not supposed to have familiar associations (as Swedish would in Finland).

3. Both surtitles retained a number of Swedish names of both characters and places to suggest the play as a reframed Mobergian narrative. The names were kept in although they are often dropped in surtitling for spatial reasons.

For technical reasons, the surtitles may have been more smoothly integrated into the performances in some performances that in others. Overall, however, they were not likely to deter audiences in Finland from seeing the play as much as they might have done, for example, in Britain where, audiences are more accustomed to dubbing, for example on TV. Marvin Carlson (2006: 55) has argued that surtitling, although a useful tool from the point of reception (it facilitates discursive comprehension), still phenomenologically increases the reception process by adding another language. I suggest that the audiences respond to this increase differently, depending on whether they come from a subtiling or dubbing (or voice-over) culture. The Nordic countries are subtitling countries where audiences have grown used to combining audial and visual codes on TV and in film. In coun-

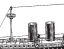

M

117 
11. tries where subtitling is rare, the production of Utvandrarna would attract only a small crowd of theatre enthusiasts; in Finland it drew full

\section{CONCLUSIONS}

Surtitles of heteroglossia which aided discursive comprehension were used in Utvandrarna as temporal, spatial and moral framing of the narratives that could be constructed of what was seen and heard on stage. It was an efficient way of framing the experience of the emigrants and draw parallels with population movements not only in our own time but throughout history. The present study prompted many new questions as well. Similarities/differences between Finnish and Swedish surtitles as part of the set would be an interesting topic to take further and so would be the dynamics of surtitling of polyphony which gave expression to a terrible longing to be understood. It also contributed to the construction of a new master narrative: Our common language is a polyphony (Lavey, 2004: 6).

RECIBIDO DICEMBRE 2008 ACEPTADO FEBRERO 2009

\section{REFERENCES}

\section{Primary Sources}

Arbabi, F. (2006). Utvandrarna. [Emigrants] [Efter Utvandrarna, Invandrarna, Nybyggarna och Sista brevet till Sverige av Vilhelm Moberg]. An unpublished theatre script.

Kynsijärvi, M. (2007). Maastamuuttajat. [Emigrants]. Surtitles for Farnaz Arbabi's Swedish production of Utvandrarna. An unpublished theatre script.

\section{Secondary Sources}

Baker, M. (2006). Translation and Conflict. A Narrative Account, London and New York: Routledge.

Carlson, M. (1990). Theatre semiotics. Signs of Life, Bloomington and Indianapolis: Indiana University Press, pp. 10-25.

Carlson, M. (2006). Speaking in Tongues. Languages at play in the Theatre, Ann Arbor: The University of Michigan Press.

Griesel, Y. (2007). Die Inzenierung als Translat. Möglichkeiten und grenzen der Theaterübertitelung, Berlin: Frank \& Timme.

- (2005). «Surtitles and translation. Towards an Integrative View of Theater Translation». MuTra, Challenges of Multidimensional Translation, Conference Proceedings, Pp.I-I4.

Hawthorn, J. (2004). A Glossary of Contemporary Literary theory. Fourth Edition. London: Arnold.

Lavey, M. (2004). «A Foreword to Tony Kushner's Homebody/Kabul", in Kushner, T. Homebody/ Kabul. Revised Version. New York: Theatre Communication Group, pp. ix-xi.

Martin, J. (1995). «Nora's Door Slam Still Reverberates Around the World». Ingmar Bergman's $A$ Doll's House in Stockholm, pp. I23-I4I.

Martin J. and Sauter, W. (I995). Understanding Theatre. Performance Analysis in Theory and Practice, Stockholm: Almqvist \& Wiksell International.

Pfister, M. (1988). The Theory and Analysis of Drama. (Orig. Das Drama, I977, translated by John Halliday). Cambridge: Cambridge University Press.

Saari, M. (2006). «Stadin ruotsi. Huomioita erään nuorisoryhmän koodin vaihtelusta. [Helsinki slang. Observations of code-alternation of a youth group]», in K. Juusela and K. Nisula (eds.) Helsinki kieliybteisönä [Helsinki as a language community], Helsingin yliopisto: Suomen kielen ja kotimaisen kirjallisuuden laitos, pp. I42-I6I.

Virkkunen, R. (2004). Aika painaa. Oopperan tekstilaitekäännöksen toiminnalliset rajat. [Time counts. The functional restrictions of the translation by a texting equipment in opera]. Tampere: Tampere University Press. 